The Bangladesh Veterinarian (2013) 30(1) : 1 - 9

\title{
In vitro study of environmental and nutritional factors on the hatching and development of eggs of Haemonchus contortus
}

\author{
F Khatun*, N Begum, S Akter and MMH Mondal \\ Department of Parasitology, Faculty of Veterinary Science, Bangladesh Agricultural \\ University, Mymensingh, Bangladesh
}

\begin{abstract}
To determine the in vitro effects of environmental and nutritional factors on the development and hatching of eggs of Haemonchus contortus, eggs were cultivated at different temperatures, humidity and $\mathrm{pH}$, in phosphate buffered saline (PBS), tap water, or normal saline, with and without faecal material and soil. No development of eggs occurred at $4^{\circ} \mathrm{C}$ up to 15 days. Hatching was maximum $(40.7 \%)$ at $30^{\circ} \mathrm{C}$ on Day 5. Maximum hatching (39.5\%) was observed on Day 6 at pH 6 and hatching was minimum (3.3\%) on Day 4 at $\mathrm{pH}$ 3. Hatching did not occur at $\mathrm{pH} 2$. At a relative humidity of 80 $90 \%$, maximum hatching $(42.2 \%)$ was recorded on Day 5. Light had no effect on development and hatching. Maximum proportion of eggs hatched in PBS containing faecal material $(40.1 \%)$. It is suggested that PBS containing faecal material may be used for the incubation of eggs of Haemonchus contortus. Best results may be obtained at $30^{\circ} \mathrm{C}, \mathrm{pH} 6$ and relative humidity 80 - 90\%. (Bangl. vet. 2013. Vol. 30, No. 1, 1 - 9)
\end{abstract}

\section{Introduction}

The hot humid climate of Bangladesh greatly favours the development and survival of parasitic nematodes. Haemonchus contortus is the most important nematode parasite in small ruminants, causing severe anaemia and high mortality. The percentage of infestation in different species of Haemonchus ranged from 50 - 85\% (Qadir, 1967). The principal feature of haemonchosis is anaemia, where the adult and the fourth larval stage suck hosts' blood. The average blood loss has been calculated as $0.05 \mathrm{~mL} /$ parasite/ day (Clark et al., 1962). Haemonchosis predominantly occurs during the rainy season all over the world (Travassoss et al., 1974; Gupta et al., 1987). Qadir (1981) reported that the peak of infestation extended from June to September in Bangladesh.

The pre-parasitic development of Haemonchus contortus in pasture is typical of trichostrongyles and depends upon the environmental temperature and moisture. Infective $\mathrm{L}_{3}$ larvae develop within 4 - 6 days in a suitable environment. The optimum temperature for development is $27^{\circ} \mathrm{C}$ with little or no development below $9^{\circ} \mathrm{C}$ (Soulsby, 1982). Developmental time varies between regions depending on prevailing weather. The eggs laid by the female Haemonchus contortus are passed in the faeces. First-stage larvae $\left(\mathrm{L}_{1}\right)$ hatch and develop to second-stage $\left(\mathrm{L}_{2}\right)$ and third-stage larvae $\left(\mathrm{L}_{3}\right)$. The $\mathrm{L}_{3}$ are free-living and able to survive for two weeks depending on

\footnotetext{
*Corresponding author:- E-mail: fahimabau@gmail.com
} 
environment and do not feed and moult until they are ingested by a suitable definitive host.

Laboratory culture of $\mathrm{L}_{3}$ is considered useful for parasitological, immunological and chemotherapeutic studies. Although the factors influencing the hatching of eggs and survival of larvae have been thoroughly studied in natural conditions, precise reports are not available in laboratory conditions. The present study was designed to find-

- The effects of temperature, $\mathrm{pH}$, humidity and light on the hatching of eggs and the development of larvae of Haemonchus contortus.

- Suitable media for the incubation of eggs

- Effects of nutrients (faecal material and soil) on the development and hatching of eggs

\section{Materials and Methods}

The study was carried out from November 2011 to April 2012. Abomasa of goats were collected from Kamal Ranjit Market of Bangladesh Agricultural University (BAU), Mymensingh.

Female parasites were crushed using pestle and mortar containing phosphate buffered saline (PBS). Eggs were counted by modified McMaster technique (Thienpont et al., 1979) using McMaster counting chamber.

Total number of eggs $/ \mathrm{mL}=($ Total eggs $\times 10) / 0.3$.

Study of the effects of temperature

Eggs were incubated at $35^{\circ} \mathrm{C}, 30^{\circ} \mathrm{C}, 20^{\circ} \mathrm{C}, 10^{\circ} \mathrm{C}$ and $4^{\circ} \mathrm{C}$. To achieve $4^{\circ} \mathrm{C}$, the culture media were kept in a refrigerator. A counted number of eggs were suspended in a petridish containing PBS. The petridishes were kept in an aluminium tray covered with a thin layer of moist cotton to prevent the evaporation of culture media. They were incubated up to 7 days and examined regularly at 24 hour intervals using a dissecting microscope. A drop of culture media was examined to see the development of eggs and the larval stages $\left(\mathrm{L}_{1}, \mathrm{~L}_{2}\right.$ and $\left.\mathrm{L}_{3}\right)$. After 15 days observation, the culture media were kept at room temperature to record the further development as described by Soulsby (1982).

\section{Study of the effects of $p H$}

To study the effects of $\mathrm{pH}$, the $\mathrm{pH}$ of the culture media were adjusted to $2,3,4,5,6,7$, 8 and 9 by adding hydrochloric acid $(\mathrm{HCl})$ into PBS drop by drop with the help of micropipette while stirring the media. The $\mathrm{pH}$ was detected by $\mathrm{pH}$ meter. Observations were made every 24 hours up to seven days using a dissecting microscope. 


\section{Study of the effects of humidity}

To determine the effects of humidity a counted number of eggs was mixed with PBS and incubated at $70-80 \%$ and $80-90 \%$ relative humidity at constant $30^{\circ} \mathrm{C}$. Hygrometer was used to measure the relative humidity in the incubator. Humidity was controlled by adding water in the petridishes. Developmental stages were observed by dissecting microscope at 24 hour intervals up to six days.

\section{Study of the effects of light}

The culture media with a counted number of eggs were covered with black cloth to exclude light but facilitate air exchange, at room temperature. Control media (PBS) was kept at room temperature in light. Observations were made in similar manner up to seven days.

\section{Study of the effects of different media}

To find suitable media for the cultivation of eggs of Haemonchus contortus, a counted number of eggs was cultured in PBS, normal saline and tap water and incubated and observed as previously described.

For the preparation of nutrient media, faeces or soil were added to the PBS. A counted number of eggs was suspended in each culture medium and incubated at room temperature up to six days. The percentage of hatching eggs was calculated every 24 hours.

\section{Statistical analysis}

Student $t$-test was used to determine the significance of differences between variables (Steel and Torrie, 1980).

\section{Results and Discussion}

\section{Effects of temperature}

There was no development of eggs at $4^{\circ} \mathrm{C}$ up to 15 days. Mizelle and Berberian (1953) recorded that $4^{\circ} \mathrm{C}$ was lethal to the ova of Haemonchus contortus. Tripathi (1980) observed no development of eggs at $4^{\circ} \mathrm{C}$ for 30 days. Miro et al. (1991) failed to collect larvae from eggs incubated at $4^{\circ} \mathrm{C}$ and these did not develop when returned to warmer temperatures. The exact mechanism of inactivation of eggs at $4^{\circ} \mathrm{C}$ could not be explained. However, it was observed that germinal mass was squeezed. Possibly low temperature caused injury to the germinal mass.

At $10^{\circ} \mathrm{C}$ eggs started to hatch on Day 4 and at $20^{\circ} \mathrm{C}$ on Day 3, and at 30 and $35^{\circ} \mathrm{C}$ eggs from Day 2. Hatching continued up to Day 5. The proportion of eggs hatching was maximum $(40.7 \%)$ at $30^{\circ} \mathrm{C}$ at Day 5 . This finding conformed to the findings of Soulsby (1982) who recorded that low temperature retarded the development of eggs and below $10^{\circ} \mathrm{C}$ little or no development took place. Islam and Ahmad (1987) recorded the hatching of eggs on Day 11 at $10^{\circ} \mathrm{C}$. At $20^{\circ} \mathrm{C}$, hatching of the eggs started at Day 3 and 
$16.5 \%$ developed to infective stage by Day 7, similar to the findings of Misra and Ruprah (1973b) who recorded $10-15 \%$ at $17-19^{\circ} \mathrm{C}$ in outdoor grass plot in Hissar, India.

Moulting started from Day 4 except at $30^{\circ} \mathrm{C}$ and $35^{\circ} \mathrm{C}$ where moulting started from Day 3. Maximum number of $\mathrm{L}_{2}(29.1 \%)$ were observed on Day 5 at $30^{\circ} \mathrm{C}$ and the highest number of $\mathrm{L}_{3}(26.8 \%)$ on Day 7 at $30^{\circ} \mathrm{C}$. The number of larvae decreased gradually from Day 6. First moulting was slightly delayed at $10^{\circ} \mathrm{C}$, at Day 5 (Table 1). Conway (1964) and Narain and Chowdhury (1979) recorded Day 4 for the hatching of eggs at $15-17^{\circ} \mathrm{C}$, and these attained $\mathrm{L}_{3}$ stage. At $30^{\circ} \mathrm{C}, 15.3 \%$ eggs hatched at Day 2 and maximum $40.7 \%$ of eggs hatched at Day 5 and larvae attained infective stage at Day 4. Rahman et al. (1996) found that eggs hatched within $1-2$ days at $26^{\circ} \mathrm{C}$ and reached infective stage within 3 - 4 days. In contrast Laha et al. (2000) recorded 17.2\%, $37.6 \%$ and $24.8 \%$ of larvae at 24,48 and 72 hours, respectively, at $25-30^{\circ} \mathrm{C}$. Embryonation ceased after 72 hours of incubation. This might be due to the media and procedure. Shahiduzzaman et al. (1999) found that hatching of eggs of Haemonchus contortus required 4 days at $20-30^{\circ} \mathrm{C}$. $\mathrm{L}_{1}$ to $\mathrm{L}_{2}$ development required 4 to 12 days. Moulting of $L_{1}$ to $L_{2}$ required a mean of 13.5 days. The percentage of infective larvae was 26.2\% at Day 8, whereas Shahiduzzaman et al. (1999) recovered 24.7\% of infective larvae at $20-30^{\circ} \mathrm{C}$. Islam and Ahmad (1987) recorded the hatching of larvae by second day in laboratory at $20-30^{\circ} \mathrm{C}$. Eggs reached $\mathrm{L}_{3}$ stage by four days. Tripathi (1977) found that $20-30^{\circ} \mathrm{C}$ was the most suitable for hatching and development of eggs of Haemonchus contortus. Similarly Misra and Ruprah (1973a) found that $22-35^{\circ} \mathrm{C}$ was suitable for development and survival of pre-parasitic stages of Haemonchus contortus.

At $35^{\circ} \mathrm{C}$, the hatching of eggs and the percentage of infective larvae were markedly depressed. Narain and Chowdhury (1979) similarly recorded $4-8$ days at $37^{\circ} \mathrm{C}$ for hatching and found that few larvae attained infective stage. Tripathi (1977) observed some eggs hatched at $40^{\circ} \mathrm{C}$ within 24 hours but few became infective larvae. Islam et al. (2005) found that most of the eggs did not hatch and $\mathrm{L}_{3}$ did not form at $40^{\circ} \mathrm{C}$. Hernandez et al. (1992) found the larval development was low and sporadic over hot and dry summer period. It is suggested that the high temperature prevents embryonic development and can kill the larvae once they are embryonated.

\section{Effects of $p H$}

Hatching did not occur at $\mathrm{pH}$ 2. Hatching started from Day 3 except at $\mathrm{pH} 3$ and 4, when hatching started from Day 4: at $\mathrm{pH} 6$ hatching started on Day 3. The proportion hatching was minimum (3.3\%) at $\mathrm{pH} 3$ on Day 4 and maximum (39.5\%) at $\mathrm{pH} 6$ on day six (Table 2). The failure of hatching at $\mathrm{pH} 2$ might be due to coagulation of the germinal mass. Sommerville and Murphy (1983) similarly observed the failure of hatching of eggs at $\mathrm{pH} 2$, due to inactive enzymes in unsheathing fluid. A negligible number of eggs (3.3\%) hatched at $\mathrm{pH} 3$. Best results were 39.5\% at $\mathrm{pH}$ 6, at Day 6. Stringfellow (1986) similarly obtained the best hatching at $\mathrm{pH}$ 6.4. Sommerville and Murphy (1983) recorded exsheathing of larvae at $\mathrm{pH}$ 6. Misra and Ruprah (1973a) 
found the maximum hatching of eggs and the optimal development of Haemonchus contortus occurred at $\mathrm{pH} 6.5$ to 8.5 in laboratory conditions, similar to the present findings. On the other hand, hatching was markedly reduced at $\mathrm{pH} 9$, which might be the due to the denaturation of the egg mass in alkaline $\mathrm{pH}$.

Table 1. Effects of temperature on the development and hatching of eggs of $H$. contortus

\begin{tabular}{|c|c|c|c|c|c|c|c|c|c|c|c|c|c|c|}
\hline \multirow{3}{*}{$\begin{array}{l}\text { Tempera- } \\
\text { ture }\left({ }^{\circ} \mathrm{C}\right)\end{array}$} & \multicolumn{5}{|c|}{ Hatching eggs (\%) } & \multicolumn{9}{|c|}{ Development of larval stages (\%) } \\
\hline & \multirow[t]{2}{*}{ D1 } & \multirow[t]{2}{*}{ D2 } & \multirow[t]{2}{*}{ D3 } & \multirow[t]{2}{*}{ D4 } & \multirow[t]{2}{*}{ D5 } & D3 & \multicolumn{2}{|c|}{ D4 } & \multicolumn{2}{|c|}{ D5 } & \multicolumn{2}{|c|}{ D6 } & \multicolumn{2}{|r|}{ D7 } \\
\hline & & & & & & L2 L3 & L2 & L3 & L2 & L3 & L2 & L3 & L2 & L3 \\
\hline 4 & & & & & & & & & & & & & & \\
\hline 10 & & & & 6.0 & 8.0a & & & & 2.5 & & 5.2 & 3.4 & 1.9 & 4.1a \\
\hline 20 & & & 19.1 & 24.4 & $31.2 b$ & & 11.3 & & 18.9 & 4.7 & 9.6 & 12.2 & 2.0 & $16.5 b$ \\
\hline 30 & & 15.3 & 29.2 & 33.3 & $40.7 \mathrm{~b}$ & 17.6 & 22.0 & 9.0 & 29.1 & 14.0 & 13.3 & 19.1 & 6.1 & $26.8 \mathrm{ab}$ \\
\hline 35 & & 7.0 & 12.8 & 22.8 & 20.5ab & 14.9 & 16.5 & 5.6 & 23.5 & 12.3 & 13.3 & 2.7 & 9.8 & $10.1 \mathrm{~b}$ \\
\hline
\end{tabular}

Values in the same row having different superscript differ significantly $(\mathrm{P}<0.05)$

Table 2. Effects of $\mathrm{pH}$ on the hatching of eggs of Haemonchus contortus

\begin{tabular}{l|cccccccc}
\hline \multicolumn{1}{c}{ Observations } & \multicolumn{7}{c}{ Proportion of eggs hatching } \\
\hline pH & 2 & 3 & 4 & 5 & 6 & 7 & 8 & 9 \\
Day 1 & - & - & - & - & - & - & - & \\
Day 2 & - & - & - & - & 5 & - & - & \\
Day 3 & - & - & - & $22.0 \mathrm{a}$ & $23.0 \mathrm{a}$ & $20.0 \mathrm{a}$ & $18.6 \mathrm{~b}$ & $4.1 \mathrm{ab}$ \\
Day 4 & - & $3.3 \mathrm{a}$ & $7.2 \mathrm{~b}$ & $23.5 \mathrm{a}$ & $29.4 \mathrm{a}$ & $23.1 \mathrm{a}$ & $20.9 \mathrm{~b}$ & $7.3 \mathrm{ab}$ \\
Day 5 & - & $5.8 \mathrm{a}$ & $12.3 \mathrm{~b}$ & $25.3 \mathrm{a}$ & $32.3 \mathrm{a}$ & $28.8 \mathrm{a}$ & $23.0 \mathrm{~b}$ & $10.2 \mathrm{ab}$ \\
Day 6 & - & $8.1 \mathrm{a}$ & $13.5 \mathrm{~b}$ & $25.1 \mathrm{a}$ & $39.5 \mathrm{a}$ & $34.5 \mathrm{a}$ & $-26.2 \mathrm{~b}$ & \\
Day 7 & - & $8.9 \mathrm{a}$ & $17.0 \mathrm{~b}$ & - & - & - & - & \\
\hline
\end{tabular}

Values in the same row having different superscript differ significantly $(\mathrm{P}<0.05)$

Effects of humidity

Hatching of eggs started at Day 3 at relative in humidity $70-80 \%$ and $80-90 \%$ at $30^{\circ} \mathrm{C}$. Hatching ceased after Day 6 in relative humidity of $70-80 \%$ and was one day earlier in case of relative humidity of $80-90 \%$. About $24 \%$ eggs hatched at Day 4 at humidity of $70-80 \%$ compared to $35 \%$ in humidity of $80-90 \%$. Maximum $(42.2 \%)$ hatching was recorded at relative humidity $80-90 \%$ at Day 5 (Table 3). These results conform to the findings of Rahman et al. (1996) who found 80\% relative humidity was favourable for hatching eggs of Haemonchus contortus: infective stage was reached within 3-4 days. Levine and Todd (1975) found more than 50\% of the eggs developed into infective stage in $90 \%$ humidity in laboratory. This differed from Shahiduzzaman et al. (1999) who recorded $24.7 \%$ infective larvae at $86 \%$ relative humidity: hatching 
required 2.5 to 7.5 days. Krecek et al. (1992) showed that as relative humidity increased, the number of larvae increased, in pasture. Fernandez et al. (1994) showed a significant difference in the time of development from eggs to infective larvae with respect to the seasons of the year: the highest recovery of first and second stage larvae obtained at the end of rainy season when the humidity was high.

Table 3. Effects of humidity on the hatching of eggs of Haemonchus contortus

\begin{tabular}{l|cc}
\hline \multicolumn{1}{c|}{ Observation } & \multicolumn{2}{c}{ Proportion of eggs hatching } \\
\hline Relative humidity (\%) & $70-\leq 80$ & $\geq 80-90$ \\
Day 1 & - & - \\
Day 2 & - & - \\
Day 3 & $20.1 \mathrm{a}$ & $31.2 \mathrm{~b}$ \\
Day 4 & $23.7 \mathrm{a}$ & $35.0 \mathrm{~b}$ \\
Day 5 & $29.1 \mathrm{a}$ & $42.2 \mathrm{~b}$ \\
Day 6 & 34.5 & - \\
\hline
\end{tabular}

Values in the same row having different superscript differ significantly $(\mathrm{P}<0.05)$

Effects of light

There was no variaation in dark and light condition for the development and hatching of eggs of Haemonchus contortus. Hatching started at Day 3 in both dark and light conditions and ceased after Day 5 (Table 4). Similar finding was observed by Islam and Ahmad (1987).

Table 4. Effects of dark and light on the hatching of eggs of Haemonchus contortus

\begin{tabular}{l|cc}
\hline \multicolumn{1}{c|}{ Observation } & \multicolumn{2}{c}{ Proportion of eggs hatching } \\
\hline Condition & Dark & Light \\
Day 1 & - & - \\
Day 2 & - & - \\
Day 3 & 25.5 & 26.3 \\
Day 4 & 28.8 & 30.2 \\
Day 5 & 33.3 & 34.0 \\
Day 6 & - & - \\
\hline
\end{tabular}

The differences are not statistically significant $(P>0.05)$

Effects of media

Hatching of eggs began at Day 4 in normal saline whereas at Day 3 in PBS and tap water. Hatching occurred at Day 2 in PBS mixed with faecal material or soil. The proportion hatching was higher (31.8\%) in PBS with faecal material followed by PBS with soil followed by PBS, tap water and then normal saline. Hatching continued up 
to 5 days. The highest proportion hatching was $40.1 \%$ in PBS containing faecal material and the lowest was $12.2 \%$ in normal saline, at Day 5. The number of larvae decreased gradually from Day 6 (Table 5).

Of the three culture media used, the highest proportion of eggs hatching was in PBS $(33.5 \%)$ followed by tap water $(24.7 \%)$ and normal saline $(12.2 \%)$ at Day 5 . Of the media containing nutrients, the best results were in PBS containing faecal material, in which $20.2 \%$ hatched at Day 2 and $40.1 \%$ by Day 5. Percentage of eggs hatching, survival and longevity of the larvae were higher in the media containing faecal material or soil. These conform to the findings of Paul (1965). The present study suggests that PBS containing faecal material and PBS containing soil may be suitable for the incubation of eggs of Haemonchus contortus. Temperature and humidity were important factors for in vitro cultivation of eggs of Haemonchus contortus.

Table 5. Effects of media on the hatching of eggs of Haemonchus contortus

\begin{tabular}{l|cccccc}
\hline \multicolumn{1}{c|}{ Media } & \multicolumn{6}{c}{ Proportion of eggs hatching } \\
\hline Day of observation & D1 & D2 & D3 & D4 & D5 & D6 \\
Normal saline (NS) & - & - & - & 9.3 & $12.2 \mathrm{a}$ & 10.3 \\
Phosphate Buffered Saline (PBS) & - & - & 28.0 & 30.7 & $33.5 \mathrm{~b}$ & 26.8 \\
Tap water & - & - & 17.8 & 21.7 & $24.7 \mathrm{ab}$ & 19.5 \\
PBS + feces & - & 20.2 & 31.8 & 38.0 & $40.1 \mathrm{a}$ & 37.5 \\
PBS + soil & - & 16.8 & 28.3 & 32.4 & $38.7 \mathrm{a}$ & 34.3 \\
\hline
\end{tabular}

Values in the same row having different superscript differ significantly $(\mathrm{P}<0.05)$

\section{Conclusions}

Temperature, humidity, $\mathrm{pH}$ and light were important factors for in vitro cultivation of eggs of Haemonchus contortus. These factors influenced the development and hatching of the eggs. Media containing nutrients (PBS + faeces) improved the development and hatching of eggs.

\section{References}

Clark CH, Kiesel GK, Goby CH 1962: Measurement of blood loss caused by the Haemonchus contortus in sheep. American Journal of Veterinary Research 23 977-980.

Conway DP 1964: Some effects of temperature on the development and activity of Haemonchus contortus. Cornell Veterinarian 54 266-270.

Fernandez RM, Vazquez PV, Liebano HE 1994: Development and recovery of Haemonchus contortus first larval stages on experimental plots in Mexico. Veterinary Parasitology 51 263-369.

Gupta RP, Yadev CL, Chaudhuri SS 1987: Epidemiology of gastrointestinal nematodes of sheep and goats in Haryana, India. Veterinary Parasitology 24 117-127. 
Hernandez EL, Prats VV, Ruiz AC 1992: Determination and estimation of the infective larvae of gastro-intestinal nematodes on pasture during two periods of the year in a humid tropical climate. Technica Pecauria en Mexico 30 31-36.

Islam KS, Ahmed S 1987: Effect of temperature, light and darkness on the hatching of eggs and development of L3 larvae of gastrointestinal helminths and migratory behaviour of larvae in grass blades. Indian Journal of Parasitology 11 45-49.

Islam MK, Begum N, Alim MA, Mondal MMH 2005: A simple method for harvesting the third-stage infective larvae of trichostrongylid nematodes of ruminants and their implications in the screening of pesticides. Bangladesh Veterinary Journal 39 49-58.

Krecek RC, Groeneveld HT, Maritz JI 1992: A preliminary study of the effect of microclimate on third-stage larvae of Haemonchus contortus and Haemonchus placei on irrigated pasture. International Journal of Parasitology 22 747-752.

Laha R, Bhattacharya D, Ramakrishna C, Sikder A 2000: In vitro egg laying capacity, percent hatchability and thereby recovery of infective larvae of Haemonchus contortus of goats. Journal of Parasitology and Applied Animal Biology 9 97-100.

Levine ND, Todd KS 1975: Micrometeorological factors involved in development and survival of free living stages of the sheep nematodes Haemonchus contortus and Trichostrongylus colubriformis. International Journal of Biometry 22 747-752.

Miro G, Meana A, Rajo VFA 1991: The effect of temperature on the development of Haemonchus contortus (Rudolphi, 1803). Medicina Veterinaria 8 473-475.

Misra SC, Ruprah NS 1973a: Effects of temperature, relative humidity and $\mathrm{pH}$ on Haemonchus contortus eggs. International Veterinary Journal 50 136-142.

Misra SC, Ruprah NS 1973b: Development of Haemonchus contortus eggs. International Veterinary Journal 50 231-233.

Mizelle JD, Berberian JA 1953: Developmental rate of the sheep stomach worm Haemonchus contortus. Processed of Indian Academic Science 62 320-321.

Narain B, Chowdhury HS 1979: Effects of temperature on the free living stages of Haemonchus contortus. Indian Biology 3 54-56.

Paul HS 1965: In vitro Cultivation Procedures for Parasitic Helminths: Advances in Parasitology 3 159-218.

Qadir ANMA 1967: Investigation on the incidence of gastro-intestinal parasites of goats in the East Pakistan Agricultural University Campus. Ceylon Veterinary Journal 15 58-61.

Qadir ANMA 1981: An observation on the seasonal influence on the gastro-intestinal nematode infection in goats under farm conditions. Bangladesh Veterinary Journal 15 11-15.

Rahman MH, Mondal MMH, Ahmed S 1996: Introduction to Helminth parasites of Animals and Birds in Bangladesh. 1st Edn. Mr. Tehsina Mostafa, Pvt. Ltd.

Shahiduzzaman AKM, Talukder MH, Rahman MH 1999: Laboratory studies on the development of pre-parasitic stages of Haemonchus contortus and Oesophagostomum radiatum. Bangladesh Veterinary Journal 33 103-106. 
Sommerville RI, Murphy CR 1983: Reversal of order of ecdysis in Haemonchus contortus (Nematoda). Journal of Parasitology 69 368-371.

Soulsby EJL 1982: Helminths, Arthropods and Protozoa of Domesticated Animals. $7^{\text {th }}$ Edn. Bailliere, London.

Steel RJ, Torrie DS 1980: Statistics of Veterinary and Animal Science, $1^{\text {st }}$ Edn, Blackwell Science Ltd., USA 41-49.

Stringfellow F 1986: Cultivation of Haemonchus contortus (Nematoda: Trichostrongylidae) from infective larvae to the adult male and the egg-laying female. Journal of Parasitology 72 339-345.

Thienpont D, Rochette F, Van POFJ 1979: Diagnosing Helminthiasis through Coprological Examination. Janseen Research Foundation, Beerse, Belgium.

Tripathi JC 1977: Effect of different temperatures on infective larvae of Haemonchus contortus under laboratory conditions. Indian Journal of Animal Science 47 739-742.

Tripathi JC 1980: Effect of different temperatures on the eggs of gastrointestinal nematodes of goats under controlled conditions. International Veterinary Journal $\mathbf{5 7}$ 719-722.

Travassoss TE, Pereire IHO, Leite ACR, Traverses HP 1974: The epizootiology of helminthiasis of goats in the bush of Pernambuca. In Congress Brasilerio de Anais, Brazil.153. Bibliografia Brasilerio de Medicinia Veterinaria Zooleenia. 1:92. CAB Abstract 72-75. 